\title{
Structural framework of the westernmost Arunachal Himalaya, NE India
}

\author{
An Yin†*, Thomas K Keltył, CS Dubey§, GE Gehrelsฯ, Q Chou†, Marty Grove† and Oscar Lovera† \\ † Department of Earth and Space Sciences and Institute of Geophysics and Planetary Physics, University of California, Los Angeles, \\ CA 90095-1567, USA \\ ¥ Department of Geological Sciences, California State University, Long Beach, California 90840-3902, USA \\ $\$$ Department of Geology, University of Delhi, Delhi 110007, India \\ I Department of Geosciences, University of Arizona, Tucson, Arizona 85721, USA \\ * To whom correspondence should be addressed.E-mail: yin@ess.ucla.edu
}

A 150-km long NW-SE traverse was mapped from Bhalukpong to Zimithang in the westernmost Arunachal Himalaya of NE India. From south to north major structures involving Cenozoic strata include the Main Frontal Thrust (MFT) placing the PlioPleistocene Kimin and Subansiri Formations (= upper Siwalik Sequence) over recent alluvial deposits, the Bhalukpong thrust within the Kimin-Subansiri strata, and the Tipi thrust juxtaposing the Miocene Dafla Formation (= Dumri Formation and lower Siwalik Group in Nepal) over the Kimin-Subanriri strata. The Main Boundary Thrust (MBT) juxtaposes Permian strata over the Dafla Formation. Both units are folded and locally develop penetrative cleavage transposing bedding. The Permian strata are in turn thrust under Proterozoic Bomdila gneiss (= Uleri gneiss in Nepal). The Bomdila gneiss is extensively mylonitized and interlayered with minor schist and phyllite belonging to the Lesser Himalayan Sequence. The gneiss is structurally repeated by five major NWdipping thrusts, which may have accommodated a significant amount of crustal shortening in the Cenozoic. Except in one place, the mylonitic Bomdila gneiss exhibits kinematic indicators dominantly suggesting top-SE sense of shear. The age of mylonitic deformation is unknown.

The Main Central Thrust (MCT) is exposed near Dirang between Bhalukpong to Zimithang. The fault zone is 100-300 $\mathrm{m}$ thick and consists of highly folded quartzite, phyllite, calcsilicate schist and kyanite-bearing leucosome veins. All folds trend N5-45 $\mathrm{W}$ and verge variably to the SE and NE. Because the folds are perpendicular to the local NE-striking trace of the MCT and subparallel to stretching lineation trending $\mathrm{N} 10-20^{\circ} \mathrm{W}$ in the MCT zone, we suggest that these folds are A-type parallel to thrust transport direction (i.e., top-SE). Neither mylonite nor mylonitic gneisses was observed within and directly above the MCT zone. Immediately above the MCT near Dirang is biotite-garnet gneiss with rare and small leucosome veins; some are folded while others severely sheared. The high-grade gneiss is part of the Greater Himalayan Crystalline Complex (GHC). Up-section from the MCT zone, the number and size of deformed and undeformed leucogranites increase. They are typically exposed as 5-50 m thick sills parallel to the regional foliation. However, locally, undeformed leucogranites also cut the foliation. Associated with the large quantity of leucogranites upsection from the MCT is the appearance of sillimenite, indicating upward increase in metamorphic grades within the GHC as noted in Nepal.

A tectonic window is observed near Lumpla about $65 \mathrm{~km}$ northwest of Dirang. There a warped low-angle fault places biotite-garnet gneiss over a quartzite unit that is interbedded with phyllite. The fault exhibits a 3-5 m thick fine-grained gouge zone. Striations and weakly developed stretching lineation in footwall phyllite trend $\mathrm{S} 40-50^{\circ} \mathrm{E}$. According to the existing regional tectonic map, the quartzite unit belongs to the Lumpla Formation that has been regarded as part of the Tethyan Himalayan Sequence (THS) resting on top of the GHC. Our field observations show that the Lumpla Formation in fact is structurally below the GHC juxtaposed by a low-angle fault. The fault, which we refer to as the Lumpla thrust, is offset between 5 and 200 meters by multiple closely spaced east-dipping normal faults. The cross-cutting relationship suggests that motion on the Lumpla thrust predates regional east-west extension.

The hanging-wall and footwall units across the Lumpla thrust are remarkably similar to those across the frontal trace of the MCT near Dirang. Correlating these lithologic units leads us to propose that the Lumpla thrust is a tectonic window of the MCT, which implies that the MCT has a minimum displacement of $65 \mathrm{~km}$ in its SE transport direction. To test this hypothesis, we conducted $\mathrm{U}-\mathrm{Pb}$ dating of detrital zircon from the quartzite units below the Lumpla window and the MCT in Dirang. The analysis was preformed at University of Arizona. We dated 100 zircon grains from each sample, with both samples yielding similar ${ }^{207} \mathrm{~Pb} /{ }^{206} \mathrm{~Pb}$ age distribution ranging from $\sim 950 \mathrm{Ma}$ to $\sim 2960 \mathrm{Ma}$. For both samples there are two prominent clusters at $1400 \mathrm{Ma}$ and $1700 \mathrm{Ma}$, respectively. These age distributions are very different from typical detrital zircon ages of the THS that usually contains a Cambro-Ordovician age pulse ( 510-480 Ma).We have also performed two types of statistical tests to determine if the two samples are statistically differentiable in terms of their zircon age populations. The analyses strongly indicate that the two samples share the same zircon age distribution. The recognition of a MCT tectonic window inside the eastern Himalaya suggests that (1) the MCT is broadly folded, a case widely recognized elsewhere and has been reported particularly in Bhutan by Indian geologists, and (2) the thickness of the GHC is much less than previously thought (i.e., $<5-7 \mathrm{~km}$ instead of $>15 \mathrm{~km}$ ) when projecting the South Tibet Detachment (STD) klippes above the GHC in nearby easternmost Bhutan.

About $20 \mathrm{~km}$ north of the Lumpla window a top-SE mylonitic shear zone $(>200 \mathrm{~m})$ is observed near Zimithang within the GHC. This shear zone, located about $10 \mathrm{~km}$ south of the IndiaChina border and about 5-7 km east of India-Bhutan border, places mylonitic augen gneiss over both non-mylonitic augen gneiss and quartzo-feldspathic gneiss. Its position and trend correspond well with the projected trace of the Kakhtang Thrust mapped in Bhutan. The latter has been interpreted to be an outof-sequence thrust younger than motion on the MCT. Geochronologic, thermochronologic, petrological analyses of the metamorphic and leucogranite samples collected from the Bhalukpong-Zimithang traverse are currently being analyzed. These data will be presented in the meeting together with a new tectonic reconstruction of the eastern Himalaya and southeastern Tibet. 